\title{
Analysis of the Health Beliefs of Physical Education and Sports Teachers Regarding Sportive Recreational Activities
}

\author{
Recep Fatih Kayhan (Corresponding author) \\ Department of Sports Management \\ Recep Tayyip Erdoğan University, Rize, Turkey
}

Tel: 90-506-446-8009Ｅ-mail: recepfatih.kayhan@rtu.edu.tr

\author{
Ümit Doğan Üstün
}

Department of Sports Management

Hatay Mustafa Kemal University, Hatay, Turkey

Tel: 90-546-898-5064Ｅ-mail: umitdoganustun@mku.edu.tr

Received: October 10, 2019 Accepted: November 20, 2019

Published: November 27, 2019

doi:10.5296/jei.v5i2.15603 URL: https://doi.org/10.5296/jei.v5i2.15603

\begin{abstract}
This paper aimed to analyze the health beliefs of physical education and sports teachers regarding sportive recreational activities in the extent of their socio-demographic features. The study sample consisted of 286 (101 male \& 185 female) physical education teachers. In the study to collect data, we used the "Health Belief Scale for Sportive Recreational Activities" scale. In analyze of the data, first, we calculated Cronbach's Alpha, Skewness and Kurtosis values. Then we used One Way Anova and Independent samples t-test at 95\% confidence level. We used Tukey's HSD as second degree test. Analyze results showed that the participants had a high level of health belief regarding sportive recreational activities. Besides, there were significant differences in the variable health belief according to marital status, and believe in the ideas that sportive recreational activities are useful for mental and physical health as well as the treatment of chronic diseases. However, there was not any significant differences according to gender and number of weekly activities performed. As a conclusion present study showed that PE \& sports teachers see sportive recreational activities
\end{abstract}


as a preventive against diseases and better health.

Keywords: Health belief, Recreational activity, Physical education teacher

\section{Introduction}

The right to life and health is one of the fundamental human rights. Contemporary health policies aimed at protecting, maintaining and improving this right, and thus concentrate on individuals' responsibilities regarding their health and enabling them to display behaviors that will improve their health (Ayaz, Tezcan, \& Akınc1, 2005). Health occupies a vital position in people's lives. As defined by the World Health Organization, health is not limited to the absence of a disease or disability and refers to a complete physical, mental, and social well-being (Çakırcal1, 2000). It is a concept that is related to all aspects of life, such as welfare, mental and emotional capacity, and psychological state. In today's world, health involves life quality and satisfaction (Edelman \& Mandle, 1998). And, a healthy lifestyle is ensured by sufficient and regular exercise, a balanced diet, non-smoking, and stress management (Esin, 1997).

We can analyze health behaviors through the health belief model. The model was first developed by a group of psychologists who worked for the United Nations Public Health Service in 1950 (Aristizabal Castano \& San Martin, 1998). Health Belief Model is the first model to have been adapted from behavioral sciences. Thanks to this model, some people started to take responsibilities in terms of protecting themselves from diseases (Stanhope \& Lancester, 2000).

We know that many diseases are because of our stressful life and participation in recreational activities is considered as one of the most effective solutions for reducing stress. Thanks to recreational activities an individual can relieve themselves, feel positive, and cleanse their minds (Bammel \& Burrus-Bammel, 1996). Derived from Latin, "recreation" can be defined as a process of restructuring and regeneration. In the Turkish language, the word is often used interchangeably with the term leisure (Üstün \& Ersoy, 2016). It is also used to refer to relieving and enjoyable activities in which an individual or social group participate in their free time (Karaküçük, 2005). The variety of recreational activities has gradually increased over time, and it started to be associated with health protection. Thanks to recreational activities, various slogans such as lifelong sports, sports for a healthy life, and wellness have been so far used to increase the number of people participating in sportive activities (Kalyon, 2000).

Because the sedentary lifestyle has recently increased as a result of technological developments, individuals have started to become less satisfied with their lives. Additionally, individuals' decreasing physical activities have resulted in different diseases and disorders within time. Recreational exercises are considered as preventive health services and have recently gained importance in Turkey and around the world. These activities positively contributed to individuals' health beliefs and commitments. In this respect in the present study we focused on physical education and sports teachers' health beliefs regarding to sportive recreational activities and tried to find out answers to the following research 
questions:

RQ1: What is the health belief level of physical education teachers regarding to sportive recreational activities?

RQ2: Is there a significant difference between married and single teachers' levels of health beliefs regarding sportive recreational activities?

RQ3: Is there a significant difference between male and female teachers' level of health beliefs regarding sportive recreational activities?

RQ4: Is there a significant difference among teachers' level of health belief regarding sportive recreational activities in terms of the number of weekly sportive recreational activities performed?

RQ5: Does the idea that recreational activities are useful for mental and physical health have a significant effect on teachers' health beliefs regarding sportive recreational activities?

RQ6: Does the idea that recreational activities are useful for the treatment of chronic diseases have a significant effect on teachers' health beliefs regarding sportive recreational activities?

\section{Material and Method}

\subsection{Study Group}

A total of 286 physical education teachers (101 male and 185 female) working in different cities participated in the study. Fifty-seven of these teachers are married, and two hundred and twenty nine of them are single.

\subsection{Data Collection Tools}

In the present study, the "Health Belief Scale for Sportive Recreational Activities" and "Personal Information Form" were used as data collection tools. Ertüzün, Bodur, and Karaküçük (2013) initially developed the scale using explanatory factor analyze method. Explanatory factor analyze method is a method that researchers use to explore the structure of their data (Osborne \& Fitzpatrick, 2012). Besides, they examined the reliability of the scale by calculating Cronbach's Alpha $(\alpha=.88)$ and test re-test correlations. The scale has five subscales as perceived seriousness (e.g., Participating in sportive recreational activities is vital for all of my body functions), perceived barriers (e.g., I am afraid of being injured while participating in sportive recreational exercises), physical benefit (e.g., I believe that my excretory system works more regularly when I do recreational exercises), psycho-social benefit (e.g., I believe that recreational exercises have positive effects on my mental health), and self-efficacy (e.g., For participating in recreational exercises, I sacrifice from my economic condition), and twenty-one items anchored with a 5-point Likert type scale (1 = strongly disagree ... 5 = strongly agree) (Ertüzün et al., 2013). Personal information form included different demographic questions addressing teachers.

\subsection{Procedure}

In the study, we collected the data online via Google Forms. First, we transformed the scale 
into the online form and mailed it to the teachers who are the members of a google group. The survey conducted voluntarily. Then we transformed the data into the SPSS for the data analysis.

\subsection{Data Analysis}

In analyze of the data first, we controlled the normality assumptions (skewness and kurtosis) and Cronbach's Alpha $(\alpha=.91)$. Then, in this respect, we applied One Way Anova and independent samples t-test as the hypothesis tests at the $95 \%$ confidence level. We also used Tukey's HSD as a second-degree test.

\section{Results}

Table 1. Total scale scores

\begin{tabular}{|l|l|l|l|l|l|l|l|l|}
\hline Scale & N & Min. & Max. & Mean & Sd. & Skewness & Kurtosis & Alpha \\
\hline $\begin{array}{l}\text { Health Belief Scale for Sportive } \\
\text { Recreational Activities }\end{array}$ & 286 & 21 & 105 & 83.85 & 15.65 & -1.217 & .895 & .91 \\
\hline
\end{tabular}

According to analyze results, skewness and kurtosis values displayed normal distribution and Cronbach's Alpha value was found to be sufficient. Besides, we found that the participants had a high level of health belief.

Table 2. T-test Result according to marital status

\begin{tabular}{|c|c|c|c|c|c|c|}
\hline Health Belief Subscales & Marital status & $\mathrm{N}$ & Mean & Sd. & $\mathrm{t}$ & $\mathrm{p}$ \\
\hline \multirow{2}{*}{ Perceived seriousness } & Married & 57 & 16.08 & 2.98 & \multirow{2}{*}{-1.241} & \multirow{2}{*}{.216} \\
\hline & Single & 229 & 15.88 & 3.43 & & \\
\hline \multirow{2}{*}{ Perceived barriers } & Married & 57 & 12.98 & 2.39 & \multirow{2}{*}{-.579} & \multirow{2}{*}{.563} \\
\hline & Single & 229 & 12.62 & 2.76 & & \\
\hline \multirow{2}{*}{ Physical benefit } & Married & 57 & 17.05 & 3.13 & \multirow{2}{*}{-.429} & \multirow{2}{*}{.668} \\
\hline & Single & 229 & 16.31 & 3.73 & & \\
\hline \multirow{2}{*}{ Psychosocial benefit } & Married & 57 & 20.33 & 4.05 & \multirow{2}{*}{-2.003} & \multirow{2}{*}{.046} \\
\hline & Single & 229 & 21.17 & 4.58 & & \\
\hline \multirow{2}{*}{ Self-efficacy } & Married & 57 & 14.63 & 2.88 & \multirow{2}{*}{-.484} & \multirow{2}{*}{.628} \\
\hline & Single & 229 & 14.86 & 3.41 & & \\
\hline \multirow{2}{*}{ Total score } & Married & 57 & 81.08 & 13.28 & \multirow{2}{*}{-1.140} & \multirow{2}{*}{.255} \\
\hline & Single & 229 & 80.86 & 16.21 & & \\
\hline
\end{tabular}


According to independent samples t-test results although there was not any significant difference in the variable health belief in the perceived seriousness, perceived barriers, physical benefit and self-efficacy subscales as well as total score, there was a significant difference in the psychosocial benefit subscale $\left(\mathrm{t}_{.05}=-2.003 ; \mathrm{p}<.05\right)$ single teachers scoring (21.17 \pm 4.58$)$ higher than married ones $(20.33 \pm 4.05)$.

Table 3. T-test Result according to gender

\begin{tabular}{|c|c|c|c|c|c|c|}
\hline Health Belief Subscales & Gender & $\mathrm{N}$ & Mean & Sd. & $\mathrm{t}$ & $\mathrm{p}$ \\
\hline \multirow{2}{*}{ Perceived seriousness } & Men & 101 & 15.59 & 3.48 & \multirow{2}{*}{.405} & \multirow{2}{*}{.686} \\
\hline & Women & 185 & 16.10 & 3.27 & & \\
\hline \multirow{2}{*}{ Perceived barriers } & Men & 101 & 12.57 & 2.76 & \multirow{2}{*}{.886} & \multirow{2}{*}{.376} \\
\hline & Women & 185 & 12.76 & 2.66 & & \\
\hline \multirow{2}{*}{ Physical benefit } & Men & 101 & 16.33 & 3.81 & \multirow{2}{*}{1.376} & \multirow{2}{*}{.170} \\
\hline & Women & 185 & 16.52 & 3.53 & & \\
\hline \multirow{2}{*}{ Psychosocial benefit } & Men & 101 & 20.28 & 4.71 & \multirow{2}{*}{-1.260} & \multirow{2}{*}{.209} \\
\hline & Women & 185 & 21.39 & 4.33 & & \\
\hline \multirow{2}{*}{ Self-efficacy } & Men & 101 & 14.6931 & 3.47777 & \multirow{2}{*}{-.483} & \multirow{2}{*}{.629} \\
\hline & Women & 185 & 14.8919 & 3.22679 & & \\
\hline \multirow{2}{*}{ Total score } & Men & 101 & 79.4851 & 16.37291 & \multirow{2}{*}{.094} & \multirow{2}{*}{.925} \\
\hline & Women & 185 & 81.6919 & 15.23573 & & \\
\hline
\end{tabular}

According to analyze results there was not any significant difference in the variable health belief according to gender in any subscales and the total score. 


\section{Macrothink}

Table 4. One Way ANOVA test results related to the number of weekly activities

\begin{tabular}{|c|c|c|c|c|c|c|}
\hline Health Belief Subscales & $\begin{array}{l}\mathrm{N} \text { of weekly performed } \\
\text { sportive recreational activities } \\
\text { (walking, jogging, etc.) }\end{array}$ & $\mathrm{N}$ & Mean & Sd. & $\mathrm{F}$ & $\mathrm{p}$ \\
\hline \multirow{3}{*}{ Perceived seriousness } & $0-2$ days & 161 & 15.91 & 2.99 & \multirow{3}{*}{.985} & \multirow{3}{*}{.375} \\
\hline & 3-5 days & 99 & 16.15 & 3.54 & & \\
\hline & 6-7 days & 26 & 15.11 & 4.49 & & \\
\hline \multirow{3}{*}{ Perceived barriers } & 0-2 days & 161 & 12.83 & 2.34 & \multirow{3}{*}{.861} & \multirow{3}{*}{.424} \\
\hline & 3-5 days & 99 & 12.62 & 2.94 & & \\
\hline & 6-7 days & 26 & 12.11 & 3.62 & & \\
\hline \multirow{3}{*}{ Physical benefit } & 0-2 days & 161 & 16.53 & 3.26 & \multirow{3}{*}{.852} & \multirow{3}{*}{427} \\
\hline & 3-5 days & 99 & 16.57 & 3.78 & & \\
\hline & 6-7 days & 26 & 15.57 & 4.99 & & \\
\hline \multirow{3}{*}{ Psychosocial benefit } & $0-2$ days & 161 & 20.72 & 4.03 & \multirow{3}{*}{.744} & \multirow{3}{*}{.476} \\
\hline & 3-5 days & 99 & 21.33 & 4.93 & & \\
\hline & 6-7 days & 26 & 21.5 & 5.39 & & \\
\hline \multirow{3}{*}{ Self-efficacy } & $0-2$ days & 161 & 14.75 & 3.06 & \multirow{3}{*}{.131} & \multirow{3}{*}{.877} \\
\hline & 3-5 days & 99 & 14.95 & 3.49 & & \\
\hline & 6-7 days & 26 & 14.73 & 4.13 & & \\
\hline \multirow{3}{*}{ Total score } & $0-2$ days & 161 & 80.76 & 13.66 & \multirow{3}{*}{.301} & \multirow{3}{*}{.740} \\
\hline & 3-5 days & 99 & 81.64 & 17.03 & & \\
\hline & 6-7 days & 26 & 79.03 & 21.34 & & \\
\hline
\end{tabular}

According to One way ANOVA results there was not any significant difference in the variable health belief in the subscales as well as the total score according to number of performed weekly sportive recreational activities $(\mathrm{p}>.05)$. 


\section{Macrothink}

Table 5. T test results related to the idea that sportive recreational activities are useful for mental and physical health

\begin{tabular}{|c|c|c|c|c|c|c|}
\hline Health Belief Subscales & $\begin{array}{l}\text { The idea that recreational } \\
\text { activities are useful for } \\
\text { mental and physical health }\end{array}$ & $\mathrm{N}$ & Mean & Sd. & $\mathrm{t}$ & $\mathrm{p}$ \\
\hline \multirow{2}{*}{ Perceived seriousness } & Yes & 252 & 16.08 & 3.36 & \multirow{2}{*}{2.224} & \multirow{2}{*}{.027} \\
\hline & No & 34 & 14.73 & 3.04 & & \\
\hline \multirow{2}{*}{ Perceived barriers } & Yes & 252 & 12.84 & 2.65 & \multirow{2}{*}{2.446} & \multirow{2}{*}{.015} \\
\hline & No & 34 & 11.64 & 2.79 & & \\
\hline \multirow{2}{*}{ Physical benefit } & Yes & 252 & 16.62 & 3.56 & \multirow{2}{*}{2.111} & \multirow{2}{*}{.036} \\
\hline & No & 34 & 15.23 & 3.92 & & \\
\hline \multirow{2}{*}{ Psychosocial benefit } & Yes & 252 & 21.29 & 4.52 & \multirow{2}{*}{3.058} & \multirow{2}{*}{.002} \\
\hline & No & 34 & 18.82 & 3.62 & & \\
\hline \multirow{2}{*}{ Self-efficacy } & Yes & 252 & 14.95 & 3.26 & \multirow{2}{*}{1.88} & \multirow{2}{*}{.061} \\
\hline & No & 34 & 13.82 & 3.52 & & \\
\hline \multirow{2}{*}{ Total score } & Yes & 252 & 81.8 & 15.54 & \multirow{2}{*}{2.666} & \multirow{2}{*}{.008} \\
\hline & No & 34 & 74.26 & 15.08 & & \\
\hline
\end{tabular}

According to independent samples $t$ test result there were significant differences in the variable health belief in perceived seriousness subscale $\left(\mathrm{t}_{.05}=2.224 ; \mathrm{p}<.05\right)$, perceived barriers subscale $\left(\mathrm{t}_{.05}=2.446 ; \mathrm{p}<.05\right)$, physical benefit subscale $\left(\mathrm{t}_{.05}=2.111 ; \mathrm{p}<.05\right)$, psycho-social benefit subscale $\left(\mathrm{t}_{.05}=3.058 ; \mathrm{p}<.01\right)$ and in the total score $\left(\mathrm{t}_{.05}=2.666 ; \mathrm{p}\right.$ $<.01)$. However, there was not any significant difference in the self-efficacy subscale $\left(\mathrm{t}_{.05}=\right.$ $1.88 ; \mathrm{p}>.05)$. 
Table 6 . $T$ test results related to the idea that sportive recreational activities are useful for the treatment of chronic diseases

\begin{tabular}{|c|c|c|c|c|c|c|}
\hline Health Belief Subscales & $\begin{array}{l}\text { The idea that recreational } \\
\text { activities are useful for the } \\
\text { treatment of chronic diseases }\end{array}$ & $\mathrm{N}$ & Mean & Sd. & $\mathrm{t}$ & $\mathrm{p}$ \\
\hline \multirow{2}{*}{ Perceived seriousness } & Yes & 234 & 16.23 & 3.36 & \multirow{2}{*}{3.362} & \multirow{2}{*}{.001} \\
\hline & No & 52 & 14.53 & 2.92 & & \\
\hline \multirow{2}{*}{ Perceived barriers } & Yes & 234 & 12.93 & 2.7 & \multirow{2}{*}{3.200} & \multirow{2}{*}{.002} \\
\hline & No & 52 & 11.63 & 2.37 & & \\
\hline \multirow{2}{*}{ Physical benefit } & Yes & 234 & 16.81 & 3.65 & \multirow{2}{*}{3.532} & \multirow{2}{*}{.000} \\
\hline & No & 52 & 14.88 & 3.1 & & \\
\hline \multirow{2}{*}{ Psychosocial benefit } & Yes & 234 & 21.22 & 4.48 & \multirow{2}{*}{1.753} & \multirow{2}{*}{.081} \\
\hline & No & 52 & 20.01 & 4.42 & & \\
\hline \multirow{2}{*}{ Self-efficacy } & Yes & 234 & 15.07 & 3.32 & \multirow{2}{*}{2.749} & \multirow{2}{*}{.006} \\
\hline & No & 52 & 13.69 & 3.04 & & \\
\hline \multirow{2}{*}{ Total score } & Yes & 234 & 82.27 & 15.69 & \multirow{2}{*}{3.178} & \multirow{2}{*}{.002} \\
\hline & No & 52 & 74.76 & 14.01 & & \\
\hline
\end{tabular}

According to independent samples $t$ test result there were significant differences in the variable health belief in perceived seriousness subscale $\left(\mathrm{t}_{.05}=3.362 ; \mathrm{p}<.001\right)$, perceived barriers subscale $\left(\mathrm{t}_{.05}=3.200 ; \mathrm{p}<.01\right)$, physical benefit subscale $\left(\mathrm{t}_{.05}=3.532 ; \mathrm{p}<.001\right)$, self-efficacy subscale $\left(\mathrm{t}_{.05}=2.749 ; \mathrm{p}<.01\right)$ and in the total score $(\mathrm{t} .05=3.178 ; \mathrm{p}<.01)$. However, there was not any significant difference in the psychosocial benefit subscale ( $\mathrm{t}_{05}=$ $1.753 ; \mathrm{p}>.05)$.

\section{Discussion and Conclusion}

This paper aimed to investigate perceived health beliefs of physical education and sports teachers related to sportive recreational activities in the extent of their personal features. In the study the analyze results revealed that physical education teachers' level of health beliefs were high. Similarly, Yalcin and Arslan (2016) reported a high level of health belief for university students. Besides, when we analyzed the effect of the marital status on teachers' level of health beliefs, we found significant differences between the married and single teachers in the psychosocial benefit sub-scale. In general, married teachers had a higher mean scale score. When we investigate the literature, we can see studies with similar or different results. For instance, a study reported that married individuals had a higher mean scale score compared to single individuals (Walker, Volkan, Sechrist, \& Pender, 1988). Furthermore, in another study, researchers found that married individuals had a higher score of health responsibility compared to single individuals and pointed out that married people had a 
higher level of healthy behaviors because marriage provided them with a natural lifestyle (Ayaz et al., 2005).

In the study, we analyzed the effect of gender on the health beliefs of the participants. However, we could not find any gender-based differences. So we can say that both male-female teachers had similar health beliefs regarding sportive recreational activities. In their study conducted on nursery students, Al-Kandari and Vidal (2007) reported no significant differences between female and male students' mean scale scores, which overlaps the findings of the present study. However, another study found a significant difference between female and male students' mean scores and the former had a higher score compared to the latter in the sub-scales of health responsibility and nutrition (Özyazıcıoğlu, Kıliç, Erdem, Yavuz, \& Afacan, 2011). Contrary to our results, Tokuç and Berberoğlu (2007) reported higher health belief for female teachers than males.

According to analyze results, the differences between participants' number of daily recreational activities did not have a significant effect on their level of health beliefs. In their study, Beydağ, Uğur, Sonakın, and Yürügen (2014) reported that students' participation in sportive and recreational activities had a significant effect on their health behaviors. So our finding showed diversity with Beydağ et al.'s (2014) findings.

Analyze results also showed that there was a significant difference in favor of physical education teachers who agreed on the idea that recreational activities are useful for mental and physical health. This significant difference observed in the mean scale and sub-scale scores. The findings demonstrated that participation in such sportive recreational activities had a significant effect on health belief regarding sportive recreational activities. This result of the study can be associated with the fact that recreational activities are mainly physical activities that contribute to both mental and physical well-being. However, in their study Likawunt, Samuel, and Yitagessu (2018) reported that only a few of the people undertook health oriented leisure activities when they seek for health. Besides, we found a significant difference in favor of physical education teachers who agreed on the idea that recreational activities are useful for the treatment of chronic diseases. Similar to the previous finding, this difference observed in the mean scale and sub-scale scores. As stated before health is a concept that is related to all aspects of life, such as welfare, mental and emotional capacity, and psychological state. In the literature various studies reported that individuals participating in physical activities were healthier (e.g., Wiese, Kuykendall, \& Tay, 2018; Yu, Hou, \& Miller, 2018).

As a conclusion present study showed that participants had a high health belief regarding to sportive recreational activities, and this belief showed difference according to marital status, the idea that sportive recreational activities are useful for mental and physical health, and the idea that sportive recreational activities are useful for the treatment of chronic diseases. So we can say that the participants see sportive recreational activities as a preventative against diseases and as a tool for a better health. However, literature showed that minority of the people who seek for health undertake health oriented leisure activities (Likawunt et al., 2018). Besides, although many health care fields have utilized social and behavioral science models 
or frame works to better understand compliance with preventative health behaviors (Gabriel, Hoch, \& Cramer, 2019) there is still lack of related research. So, we believe that present study is likely to contribute to the both existing and future studies when it comes to health belief regarding recreation and exercise. However, further studies must analyze the relationship between sportive recreational activities and possible effects on public health in depth.

\section{References}

Al-Kandari, F., \& Vidal, V. L. (2007). Correlation of the health-promoting lifestyle, enrollment level, and academic performance of college of nursing students in Kuwait. Nurs Health Sci, 9(2), 112-119. https://doi.org/10.1111/j.1442-2018.2007.00311.x

Aristizabal Castano, I., \& San Martin, R. L. (1998). Health habits of health professionals. Rev Enferm, 21(237), 15-18.

Ayaz, S., Tezcan, S., \& Akıncı, F. (2005). Hemşirelik yüksekokulu öğrencilerinin sağlığı geliştirme davranışları. Cumhuriyet Üniversitesi Hemşirelik Yüksek Okulu Dergisi, 9(2), 26-34.

Bammel, G., \& Burrus-Bammel, L. L. (1996). Leisure and human behavior (3rd ed.). USA: Brown \& Benchmark Publishers.

Beydağ, K. D., Uğur, E., Sonakın, C., \& Yürügen, B. (2014). Sağlık ve yaşam dersinin üniversite öğrencilerinin sağlıklı yaşam biçimi davranışlarına etkisi. Gümüşhane Üniversitesi Sağlık Bilimleri Dergisi, 3(1), 599-609.

Çakırcalı, E. (2000). Hasta bakımı ve tedavisinde temel ilke ve uygulamalar. İzmir: Güven \& Nobel Tip Kitapevleri.

Cihangiroğlu, Z., \& Deveci, S. E. (2011). Fırat Üniversitesi Elazığ Sağlık Yüksekokulu öğrencilerinin sağlıklı yaşam biçimi davranışları ve etkileyen faktörler. Fırat Tıp Dergisi, 16(2), 78-83.

Edelman, C. L., \& Mandle, C. L. (1998). Health promotion throughout the life span. Philadelphia: Mosby Comp.

Ertüzün, E., Bodur, S., \& Karaküçük, S. (2013). The development of health-belief scale on sportive recreational activities. Procedia-Social and Behavioral Sciences, 89, 509-516. https://doi.org/10.1016/j.sbspro.2013.08.884

Esin, N. (1997). Endüstriyel alanda çalışan işçilerin sağlık davranışlarının saptanması ve geliştirilmesi (Phd Thesis, İstanbul Üniversitesi SAğlık Bilimleri Enstitüsü, İstanbul).

Gabriel, E. H., Hoch, M. C., \& Cramer, R. J. (2019). Health belief model scale and theory of planned behavior scale to assess attitudes and perceptions of injury prevention program participation: An exploratory factor analysis. Journal of Science and Medicine in Sport, 22, 544-549. https://doi.org/10.1016/j.jsams.2018.11.004

Kalyon, T. A. (2000). Spor hekimliği (5th ed.). Ankara: Gata Yayınları. 


\section{Macrothink}

Journal of Educational Issues

ISSN 2377-2263

2019, Vol. 5, No. 2

Karaküçük, S. (2005). Rekreasyon: Boş zamanları değerlendirme (5th ed.). Ankara: Gazi Kitabevi.

Likawunt, S. A., Samuel, Y. A., \& Yitagessu, H. A. (2018). Health-seeking behavior and associated factors among community in Southern Ethiopia: Community based cross-sectional study guided by Health belief model (pp. 1-23). Cold Spring Harbor Laboratory. https://doi.org/10.1101/388769

Osborne, J. W., \& Fitzpatrick, D. C. (2012). Replication analysis in exploratory factor analysis: What it is and why it makes your analysis better. Practical Assessment, Research \& Evaluation, 17(15). Retrieved from http://pareonline.net/getvn.asp? $\mathrm{v}=17 \& \mathrm{n}=15$

Özyazıcıoğlu, N., Kılıç, M., Erdem, N., Yavuz, C., \& Afacan, S. (2011). Hemşirelik öğrencilerinin sağlıklı yaşam biçimi davranışlarının belirlenmesi. Uluslararası İnsan Bilimleri Dergisi, 8(2), 277-332.

Stanhope, M., \& Lancester, J. (2000). Community public health nursing (50th ed.). St. Louis, Toronto: Mosby.

Tokuç, B., \& Berberoğlu, U. (2007). Edirne merkez ilçe ilköğretim okullarında çalışan öğretmenlerde sağlığı geliştirici davranışlar. TSK Koruyucu Hekimlik Bülteni, 6, 421-426.

Üstün, Ü. D., \& Ersoy, A. (2016). Sosyolojik ve psikolojik açılardan rekreasyon (1st ed.). İzmir: Ergün Basın Yayın.

Walker, N. S., Volkan, K., Sechrist, R. K., \& Pender, J. N. (1988). Health promoting life styles of older adults: Comparisons with young and middle-aged adults, correlates and patterns. Adv Nurs Sci, 11(1), 76-90. https://doi.org/10.1097/00012272-198810000-00008

Wiese, W. C., Kuykendall, L., \& Tay, L. (2018). Get active? A meta-analysis of leisure-time physical activity and subjective well-being. The Journal of Positive Psychology, 13(1), 57-66. https://doi.org/10.1080/17439760.2017.1374436

Yalcin, B., \& Arslan, F. (2016). Health beliefs of university students with regard to sportive recreational activities: The case of Batman and Gümüşhane Universities. International Journal of Health Management and Tourism, 1(1), 2-13.

Yu, C. Y., Hou, S. I., \& Miller, J. (2018). Health for older adults: The role of social capital and leisure-time physical activity by living arrangements. Journal of Physical Activity \& Health, 15(2), 150-158. https://doi.org/10.1123/jpah.2017-0006

\section{Copyright Disclaimer}

Copyright for this article is retained by the author(s), with first publication rights granted to the journal.

This is an open-access article distributed under the terms and conditions of the Creative Commons Attribution license (http://creativecommons.org/licenses/by/3.0/). 